\title{
Sternmagnolien
}

Bildnachweis

Pipdowntown

Dreamstime.com

he.meierhans[at]bluewin.ch

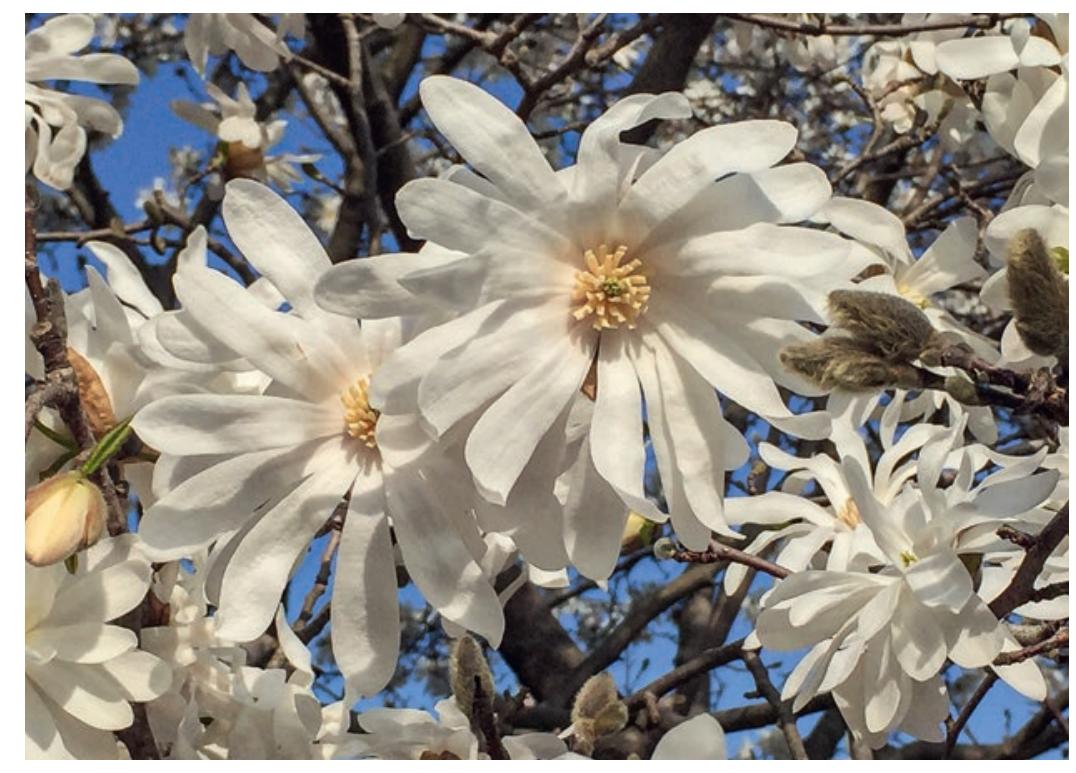

Sterne, die am Tag

Leuchten, erinnern mich an

Die frühe Kindheit

Das Stumme spricht an

In meinem Mädchenauge

Lächelt der Frühling

Die ersten Veilchen

Fand ich bei der sehr grossen

Linde in Uster

Die Freude in den

Kinderaugen ist wohl die

Reinste der Sterne.

Dr. med. Hedi Meierhans

\section{Die Fliege}

Bildnachweis

Sylt | Impressionen 2006 | Acrylmischtechnik $80 \times 60 \mathrm{~cm}$ Harriet Keller-Wossidlo

harriet.keller[at]hotmail.ch
Die Fliege, die verirrt den Ausweg sucht wie eine Möwe, die das Meer nicht findet und glaubt die Schaumkronen als Wolken

Sie geben ihr Leben aus, zerreissen ihr Weh wie dünne Netze

auch Balken zerbersten ohne Schrei wie Musik in verödeten Ohren aber Sonne ist nur Finsternis im Inneren der Figur -

Dr. med. Harriet Keller-Wossidlo

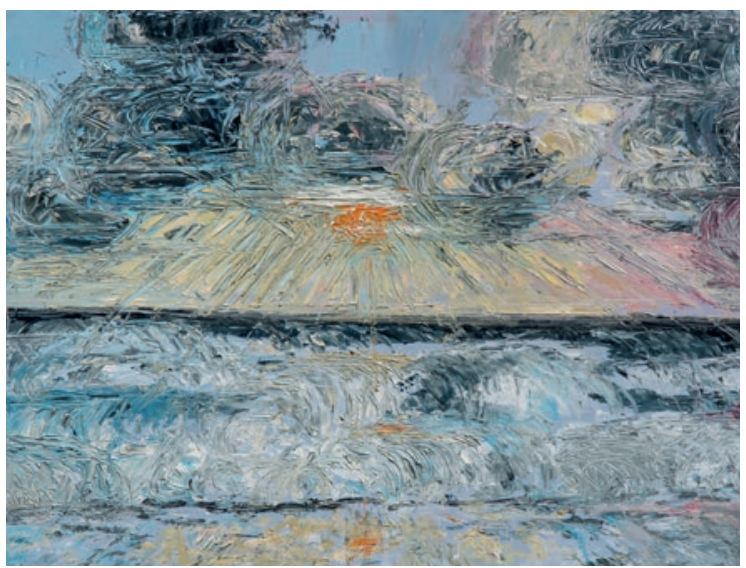

